\title{
EFFECTS OF BORON AND VERMICOMPOST ON GROWTH, YIELD AND NUTRIENT CONTENT OF CHILLI (Capsicum annum L.)
}

\author{
Nawrin, K. S., M. J. Uddin, A. H. M. Z. Ali and M. K. Rahman \\ Department of Soil, Water and Environment, University of Dhaka, Dhaka-1000, Bangladesh
}

\begin{abstract}
The effects of boron (B) and vermicompost (VC) on growth and yield of Chilli (Capsicum annum L.) and nutrient accumulation in its fruits was examined. The highest plant height $(22 \mathrm{~cm})$, leaf number per plant (73), leaf area $\left(502.53 \mathrm{~cm}^{2} /\right.$ plant), dry weight $(22.27 \mathrm{~g} / \mathrm{plant})$, fruit length $(8.97 \mathrm{~cm})$, fruit number per plant (6), fruit yield (11.76 g/plant) were recorded in $\mathrm{B}_{0.5} \mathrm{~kg} / \mathrm{ha}+\mathrm{VC}_{5}$ ton/ha at harvest. The results of growth and yield of Chilli varied significantly $(\mathrm{p}<0.05)$ and increased with time. The total nutrient concentrations in the fruits were measured and varied significantly $(\mathrm{p}<0.05)$. The highest concentration of total $\mathrm{P}(0.028 \%), \mathrm{K}$ $(2.50 \%), \mathrm{S}(0.20 \%), \mathrm{Cu}(8.0 \mathrm{mg} / \mathrm{kg}), \mathrm{Fe}(410 \mathrm{mg} / \mathrm{kg})$ and $\mathrm{Mn}(0.80 \mathrm{mg} / \mathrm{kg})$ in the fruit were observed in $\mathrm{B}_{0.5}$ $\mathrm{kg} / \mathrm{ha}+\mathrm{VC}_{5}$ ton/ha treatment and total $\mathrm{N}(0.41 \%)$ and $\mathrm{Zn}(3.50 \mathrm{mg} / \mathrm{kg})$ were found in $\mathrm{B}_{1.5} \mathrm{~kg} / \mathrm{ha}+\mathrm{VC}_{5}$ ton $/ \mathrm{ha}$ treatment. The overall best growth, yield and nutrient accumulation in the fruits of Chilli was achieved in $\mathrm{B}_{0.5}$ $\mathrm{kg} / \mathrm{ha}+\mathrm{VC}_{5} \mathrm{t} / \mathrm{ha}$ treatment.
\end{abstract}

Key words: Boron; Chilli; Growth; Nutrient accumulation; Vermicompost.

\section{INTRODUCTION}

Vermicompost is the excreta of earthworms, which are rich in humus, macronutrients, and micronutrients that can improve and enhance crop production (Adhikary, 2012; Azarmi et al. 2008). Vermicompost to the soil is very beneficial, in increasing nutrient availability (Roy et al. 2006) and improve the growth and fruit yield (Theunissen et al. 2010). Chilli is a rich source of vitamins $\mathrm{A}, \mathrm{C}$ and E where 100 gram of edible portion contains $24 \mathrm{k}$ cal of energy, $1.3 \mathrm{~g}$ of protein, $4.3 \mathrm{~g}$ of carbohydrate and $0.3 \mathrm{~g}$ of fat (Vijayalakshmi and Gayathri, 2017). Considering the above nutritional value, an experiment was undertaken to investigate the effect of vermicompost and boron on growth, yield and nutrient contents of fruit of Chilli (Capsicum annum L.).

\section{METERIAL AND METHODS}

\section{Soil sample collection and some physical and chemical properties}

Soil sample $(0-15 \mathrm{~cm}$ depth) was collected from Dhamrai Upazila following composite sampling method. The sample was air dried and ground and sieved through $2 \mathrm{~mm}$ sieve. The soil had a $\mathrm{pH}$ of 7.54 (Jackson, 1965), electrical conductivity 49.9 ds/m (Jackson, 1965), organic carbon $0.16 \%$ (Walkley and Black, 1934), organic matter 0.27\%, available nitrogen 0.016\% (Kjeldahl extraction; Jackson, 1965), available phosphorus $0.042 \%$ (blue color method using ascorbic acid, Olsen et al. 1954), exchangeable potassium $0.030 \%$ (Pratt, 1965), available sulphur 0.0048\% (Turbidimetric method, Bardsley and Lancaster, 1965). The concentrations of total iron was $2310 \mathrm{mg} / \mathrm{kg}$, manganese $421 \mathrm{mg} / \mathrm{kg}$, zinc 75 $\mathrm{mg} / \mathrm{kg}$ and copper $26 \mathrm{mg} / \mathrm{kg}$ were determined using an atomic absorption spectrophotometer followed by Mordtvedt et al. (1991).

\section{Preparation and properties of vermicompost}

Vermicompost was prepared and collected from the crop field of Soil Resource Development Institute (SRDI). In this process, the digestive tracts of certain earthworm species (e.g. Eisenia fetida) were used to stabilize cow dung. The final product is an odourless peat like substance. Some chemical properties of vermicompost were mentioned in Table 1. 
Table 1. Chemical properties of the processed vermicompost.

\begin{tabular}{|c|c|c|}
\hline Parameters & Chemical properties & Analytical methods used \\
\hline $\mathrm{pH}$ & 6.54 & Jackson, 1965 \\
\hline Organic carbon $(\%)$ & 9.87 & - \\
\hline Organic matter $(\%)$ & 17.01 & Walkley and Black, 1934 \\
\hline $\mathrm{C}: \mathrm{N}$ ratio & 8.54 & - \\
\hline Total nitrogen $(\%)$ & 1.25 & Kjeldahl extraction (Jackson, 1965) \\
\hline Total phosphorus (\%) & 0.059 & Blue color method using ascorbic acid, (Olsen et al. 1954) \\
\hline Total potassium $(\%)$ & 0.242 & (Pratt, 1965) \\
\hline Available Fe (mg/kg) & 0.11 & (Jackson, 1965) \\
\hline Available Mn " & 0.69 & " \\
\hline Available Zn " & 2.17 & $"$ \\
\hline Available $\mathrm{Cu} " \prime$ & 0.01 & $"$ \\
\hline Available B " & 0.601 & $"$ \\
\hline
\end{tabular}

\section{Pot experiment}

A pot experiment was carried out in the net house of the Department of Soil, Water and Environment, University of Dhaka. Eight kilograms of air dried soil were placed in $10 \mathrm{~kg}$ capacity pot providing a drainage hole at the bottom. Eight treatments with three replications were as follows: control (-B and VC), $\mathrm{VC}_{5}$ ton/ha, $\mathrm{B}_{0.5} \mathrm{~kg} / \mathrm{ha}, \mathrm{B}_{1.0} \mathrm{~kg} / \mathrm{ha}, \mathrm{B}_{1.5} \mathrm{~kg} / \mathrm{ha}, \mathrm{B}_{0.5} \mathrm{~kg} / \mathrm{ha}+\mathrm{VC}_{5}$ ton/ha, $\mathrm{B}_{1.0} \mathrm{~kg} / \mathrm{ha}+\mathrm{VC}_{5}$ ton/ha, and $\mathrm{B}_{1.5} \mathrm{~kg} / \mathrm{ha}+\mathrm{VC}_{5}$ ton/ha. Pots were arranged in a completely randomized design (CRD). Urea, TSP and MP fertilizers were applied in quantities of $20 \mathrm{~kg} / \mathrm{ha}, 15 \mathrm{~kg} / \mathrm{ha}$ and $30 \mathrm{~kg} / \mathrm{ha}$, respectively in each pot as basal dose. Boron was used as boric acid. Certified seeds of Chilli, (Capsicum annum L.) were collected from 'quality seed company', Siddique Bazar, Dhaka. Three healthy seeds were sown to each pot and water was applied up to field capacity. One healthy seedling was kept in each pot. The pots were watered thrice a week in the morning. Plant height, the number of leaf and leaf area per plant were recorded at 60 and 120 days.

\section{Harvesting}

The plants were harvested as root, stem, leaf and fruit. The roots were washed with tap water and finally with distilled water to remove any adhering particles on the root surface. Samples were air dried in room temperature and finally oven-dried at $65^{\circ} \mathrm{C}$ for 48 hours in the laboratory. The dry weight of the samples was recorded and the samples were ground with a mechanical grinder and stored in plastic containers for further chemical analysis. For nitrogen, $0.5 \mathrm{~g}$ of yield (fruit) sample was digested in a Kjeldhal digestion flask (Jackson, 1965), for P and K $0.5 \mathrm{~g}$ yield (fruit) was digested (Jackson, 1965). Phosphorus of the digest was determined by vanadomolybdophophoric yellow color method at $430 \mathrm{~nm}$ using spectrophotometer (model DR 5000). Potassium in the digest was determined by using JENWAY flame photometer (model PFP 7). For sulfur $0.5 \mathrm{~g}$ yield (fruit) sample was digested with $\mathrm{HNO}_{3}-\mathrm{HClO}_{4}$ acid. After digestion, the extract was used to determine the total sulfur content by turbidimetric method (Bardsley and Lancaster, 1965). For total $\mathrm{Cu}, \mathrm{Fe}, \mathrm{Zn}$ and $\mathrm{Mn}$ were determined by the atomic absorption spectrophotometer (VARIAN AA240). LSD tests of the result were performed using IBMSPSS, version 25.

\section{RESULTS AND DISCUSSION}

Plant growth, yield and nutrient accumulation in the fruits were assessed in terms of plant height, leaf number, leaf area and yield attributes (Table 2), and macro and micro nutrients concentration in the fruits of chili plants (Table 3). Height, leaf number and leaf area of chilli plant increased with time and varied significantly $(\mathrm{p}<0.05)$ (Table 2$)$. However, the highest plant height $(22 \mathrm{~cm})$ was observed in $\mathrm{B}_{0.5}$ 
$\mathrm{kg} / \mathrm{ha}+\mathrm{VC}_{5}$ ton/ha treatment. Singh et al. (2008) reported that vermicompost application potentially increases plant spread, leaf area, dry matter and fruit yield in strawberry plants.

The highest leaf number was recorded 73 in $\mathrm{B}_{0.5} \mathrm{~kg} / \mathrm{ha}+\mathrm{VC}_{5}$ ton/ha treatment at harvest. It was found that the number of leaf significantly increased with the combined application of organic and inorganic fertilizer. Pettter et al. (2012) confirmed that integrated application of organic and inorganic fertilizers significantly increased plant growth and crop productivity. Khadir et al. (2002) also observed that combined application of different inorganic and organic fertilizers increased both vegetative and leaf number in cabbage. Leaf area was maximum $\left(502.53 \mathrm{~cm}^{2} /\right.$ plant $)$ in $\mathrm{B}_{0.5} \mathrm{~kg} / \mathrm{ha}+\mathrm{VC}_{5}$ ton/ha treatment. The application of vermicompost in combination with chemical fertilizer resulted in higher leaf area index. Similar result was recorded by Jeyabal and Kuppuswamy (2001), reported that with a higher leaf area index, plants become photosynthetically more active, which would contribute to the improvement in yield attributes. Vermicompost contained numerous humic acids, which enhances the number of leaf, leaf area index, plant height and ultimately increased the growth rate (Atarzadeh et al. 2013).

Table 2. Effects of Boron and Vermicompost on the height $(\mathrm{cm})$, leaf number (number/plant), leaf area $\left(\mathrm{cm}^{2} / \mathrm{plant}\right)$ and yield attributes of Chilli plants.

\begin{tabular}{|c|c|c|c|c|c|c|c|c|c|c|}
\hline Treatments & $\begin{array}{c}\text { Plant } \\
\text { height } \\
\text { at } \\
120 \\
\text { days } \\
\end{array}$ & $\begin{array}{c}\text { Leaf } \\
\text { number } \\
\text { at } \\
\mathbf{1 2 0} \\
\text { days } \\
\end{array}$ & $\begin{array}{c}\begin{array}{c}\text { Leaf } \\
\text { area } \\
\text { at } \\
120 \\
\text { days }\end{array} \\
\end{array}$ & $\begin{array}{c}\text { Dry } \\
\text { weight } \\
\text { of root } \\
\text { (g/ } \\
\text { plant) }\end{array}$ & $\begin{array}{c}\text { Dry } \\
\text { weight } \\
\text { of shoot } \\
\text { (g/ } \\
\text { plant) }\end{array}$ & $\begin{array}{c}\text { Dry } \\
\text { weight } \\
\text { of leaf } \\
\text { (g/ } \\
\text { plant) } \\
\end{array}$ & $\begin{array}{c}\text { Total } \\
\text { (g/ } \\
\text { plant) }\end{array}$ & $\begin{array}{c}\text { Fruit } \\
\text { length } \\
(\mathrm{cm})\end{array}$ & $\begin{array}{c}\text { Fruit } \\
\text { number }\end{array}$ & $\begin{array}{c}\text { Fruit } \\
\text { yield } \\
\text { (g/ } \\
\text { plant) }\end{array}$ \\
\hline Control (-B and VC & 11.51 & 53.01 & 295.79 & 3.17 & 6.66 & 8.14 & 17.97 & 5.62 & 2 & 6.93 \\
\hline $\mathrm{VC}_{5}$ ton $/ \mathrm{ha}$ & 17.50 & 69.23 & 346.05 & 3.63 & 8.63 & 7.18 & 19.44 & 8.85 & 5 & 11.63 \\
\hline $\mathrm{B}_{0.5} \mathrm{~kg} / \mathrm{ha}$ & 14.00 & 55.87 & 357.51 & 2.36 & 8.05 & 10.63 & 21.04 & 6.68 & 4 & 10.76 \\
\hline $\mathrm{B}_{1} \mathrm{~kg} / \mathrm{ha}$ & 17.00 & 62.33 & 324.71 & 3.27 & 6.78 & 11.5 & 21.55 & 6.64 & 5 & 11.22 \\
\hline $\mathrm{B}_{1.5} \mathrm{~kg} / \mathrm{ha}$ & 13.50 & 67.46 & 305.68 & 3.80 & 7.93 & 9.50 & 21.23 & 8.29 & 5 & 10.58 \\
\hline $\mathrm{B}_{0.5} \mathrm{~kg} / \mathrm{ha}+\mathrm{VC}_{5}$ ton $/ \mathrm{ha}$ & 22.00 & 73.00 & 502.53 & 4.25 & 8.88 & 9.14 & 22.27 & 8.97 & 6 & 11.76 \\
\hline $\mathrm{B}_{1.0} \mathrm{~kg} / \mathrm{ha}+\mathrm{VC}_{5}$ ton $/ \mathrm{ha}$ & 14.00 & 72.82 & 448.79 & 2.67 & 6.24 & 8.84 & 17.75 & 7.33 & 5 & 10.95 \\
\hline $\mathrm{B}_{1.5} \mathrm{~kg} / \mathrm{ha}+\mathrm{VC}_{5}$ ton $/ \mathrm{ha}$ & 13.50 & 58.94 & 337.20 & 1.62 & 6.64 & 7.39 & 15.65 & 7.33 & 4 & 10.95 \\
\hline LSD at $5 \%$ & 0.750 & 1.048 & 0.987 & 0.727 & 1.036 & 2.953 & - & 0.89 & 0.84 & 1.33 \\
\hline
\end{tabular}

\section{Dry matter yield}

Dry weights of root, stem and leaf are presented in Table 2 varied significantly $(\mathrm{p}<0.05)$. The highest yields of root, stem and leaf were achieved due to the combined application of inorganic and organic fertilizer in $\mathrm{B}_{0.5} \mathrm{~kg} / \mathrm{ha}+\mathrm{VC}_{5}$ ton/ha treatment. The highest dry weight was found $(22.27 \mathrm{~g} / \mathrm{plant})$, in $\mathrm{B}_{0.5}$ $\mathrm{kg} / \mathrm{ha}+\mathrm{VC}_{5}$ ton/ha treatment. Results of the fruit length and fruit number per plant of chilli during harvest, (Table 2) varied significantly $(\mathrm{p}<0.05)$. The maximum fruit length $(8.97 \mathrm{~cm})$ of chilli was observed in $\mathrm{B}_{0.5} \mathrm{~kg} / \mathrm{ha}+\mathrm{VC}_{5}$ ton/ha treatment. The second highest fruit length $(8.85 \mathrm{~cm})$ was found in $\mathrm{VC}_{5}$ ton/ha treatment. The lowest fruit length $(5.62 \mathrm{~cm})$ was observed in control. The maximum number of fruit per plant was six, observed in $\mathrm{B}_{0.5} \mathrm{~kg} / \mathrm{ha}+\mathrm{VC}_{5}$ ton/ha treatment. The second highest number of fruit per plant was five, recorded in $\mathrm{VC}_{5}$ ton/ha, $\mathrm{B}_{1} \mathrm{~kg} / \mathrm{ha}, \mathrm{B}_{1.5} \mathrm{~kg} / \mathrm{ha}$ and $\mathrm{B}_{1} \mathrm{~kg} / \mathrm{ha}+\mathrm{VC}_{5}$ ton/ha treatments, respectively. The minimum number of fruit per plant was two, found in control. This increase in yield attributes might be due to the high levels of organic nutrients of vermicompost that could boost up the vegetative growth of chilli plants to accelerate the photosynthetic rate. Treatments that received vermicompost significantly increased yield compared to control. However, the maximum fruit yield (11.76 g/plant) obtained in combination of $\mathrm{B}$ and vermicompost; in $\mathrm{B}{ }_{0.5} \mathrm{~kg} / \mathrm{ha}+\mathrm{VC}_{5}$ ton/ha treatment. Hossain et al. (2012) noted that vermicompost potentially enhances higher yields in tomato plants rather than other fertilizers. 
Mean values of total macro and micro nutrient concentrations in the fruits of Chilli as affected by boron and vermicompost are presented in Table 3 . The results varied significantly $(\mathrm{p}<0.05)$ at $5 \%$ level. The $\mathrm{N}$ concentration in the fruits ranged from 0.13 to $0.41 \%$ among the treatments. The highest $\mathrm{N}$ concentration $(0.41 \%)$ was recorded in $\mathrm{B}_{1.5} \mathrm{~kg} / \mathrm{ha}+\mathrm{VC}_{5}$ ton/ha treatment. The lowest concentration of $\mathrm{N}$ was observed in control treatment. $\mathrm{P}$ concentration ranged from 0.019 to $0.028 \%$ among the treatments. The highest $\mathrm{P}$ concentration $(0.028 \%)$ was recorded in the fruits was obtained in $\mathrm{B}_{0.5} \mathrm{~kg} / \mathrm{ha}$ $+\mathrm{VC}_{5}$ ton/ha treatment. The highest total $\mathrm{K}$ concentration $(2.50 \%)$ in the fruits was obtained in $\mathrm{B}_{0.5}$ $\mathrm{kg} / \mathrm{ha}+\mathrm{VC}_{5}$ ton/ha treatment. The second highest $\mathrm{K}$ concentration $(2.40 \%)$ was found in $\mathrm{B}_{1.5} \mathrm{~kg} / \mathrm{ha}$ treatment. The highest total S concentration $(0.20 \%)$ in the fruits was obtained in $\mathrm{B}_{0.5} \mathrm{~kg} / \mathrm{ha}+\mathrm{VC}_{5}$ ton/ha treatment. The lowest total N $(0.13 \%), \mathrm{P}(0.019 \%), \mathrm{K}(1 \%)$, and $\mathrm{S}(0.03 \%)$ were observed in control. The highest total $\mathrm{Cu}(8.0 \mathrm{mg} / \mathrm{kg})$ in the fruits was obtained in $\mathrm{B}_{0.5} \mathrm{~kg} / \mathrm{ha}+\mathrm{VC}_{5}$ ton/ha treatment. The highest total $\mathrm{Zn}(3.5 \mathrm{mg} / \mathrm{kg})$ in the fruits was obtained in $\mathrm{B}_{1.5} \mathrm{~kg} / \mathrm{ha}+\mathrm{VC}_{5}$ ton $/$ ha treatment. The highest total $\mathrm{Fe}(210 \mathrm{mg} / \mathrm{kg})$ and $\mathrm{Mn}(0.8 \mathrm{mg} / \mathrm{kg})$ in fruits were obtained in $\mathrm{B}_{0.5} \mathrm{~kg} / \mathrm{ha}+\mathrm{VC}_{5}$ ton/ha treatment. The lowest total $\mathrm{Cu}(4.0 \mathrm{mg} / \mathrm{kg}), \mathrm{Zn}(1.6 \mathrm{mg} / \mathrm{kg}), \mathrm{Fe}(120 \mathrm{mg} / \mathrm{kg})$, and $\mathrm{Mn}(0.1 \mathrm{mg} / \mathrm{kg})$ were recorded in control. The maximum amount of total macro and micro nutrient concentrations in the fruits of Chilli was possibly due to proper doses of organic and inorganic fertilizers in $\mathrm{B}_{0.5} \mathrm{~kg} / \mathrm{ha}+\mathrm{VC}_{5}$ ton/ha and $\mathrm{B}$ $1.5 \mathrm{~kg} / \mathrm{ha}+\mathrm{VC}$ ton/ha treatments. Zaman et al. (2018) reported that vermicompost along with different rates of chemical fertilzers exerted significant influence on the growth, leaf biomass yield and stevioside content of stevia.

Table 3. Effects of Boron and Vermicompost on macro and micro nutrients concentration in the fruits of Chilli plants.

\begin{tabular}{lcccccccc}
\hline \multicolumn{1}{c}{ Treatments } & $\mathbf{N}(\%)$ & $\mathbf{P}(\%)$ & $\mathbf{K}(\%)$ & $\mathbf{S}(\%)$ & $\begin{array}{c}\mathbf{C u} \\
(\mathbf{m g} / \mathbf{k g})\end{array}$ & $\begin{array}{c}\mathbf{Z n} \\
(\mathbf{m g} / \mathbf{k g})\end{array}$ & $\begin{array}{c}\mathbf{F e} \\
(\mathbf{m g} / \mathbf{k g})\end{array}$ & $\begin{array}{c}\mathbf{M n} \\
(\mathbf{m g} / \mathbf{k g})\end{array}$ \\
\hline Control (-B and VC & 0.13 & 0.019 & 1.00 & 0.03 & 4 & 1.6 & 120 & 0.1 \\
$\mathrm{VC}_{5}$ ton/ha & 0.34 & 0.024 & 2.40 & 0.19 & 5 & 1.9 & 210 & 0.7 \\
$\mathrm{~B}_{0.5} \mathrm{~kg} / \mathrm{ha}$ & 0.31 & 0.027 & 1.90 & 0.19 & 4 & 1.9 & 150 & 0.7 \\
$\mathrm{~B}_{1} \mathrm{~kg} / \mathrm{ha}$ & 0.33 & 0.026 & 1.40 & 0.06 & 5 & 2.8 & 210 & 0.2 \\
$\mathrm{~B}_{1.5} \mathrm{~kg} / \mathrm{ha}$ & 0.34 & 0.020 & 2.40 & 0.10 & 6 & 1.8 & 160 & 0.4 \\
$\mathrm{~B}_{0.5} \mathrm{~kg} / \mathrm{ha}+\mathrm{VC}_{5}$ ton/ha & 0.40 & 0.028 & 2.50 & 0.20 & 8 & 2.2 & 210 & 0.8 \\
$\mathrm{~B}_{1.0} \mathrm{~kg} / \mathrm{ha}+\mathrm{VC}_{5}$ ton/ha & 0.31 & 0.025 & 1.53 & 0.19 & 5 & 2.8 & 130 & 0.7 \\
$\mathrm{~B}_{1.5} \mathrm{~kg} / \mathrm{ha}+\mathrm{VC}_{5}$ ton/ha & 0.41 & 0.026 & 1.40 & 0.10 & 5 & 3.5 & 140 & 0.7 \\
$\mathrm{LSD}$ at 5\% & .007 & 0.041 & .342 & .005 & .051 & .002 & .001 & .008 \\
\hline
\end{tabular}

The results revealed that $\mathrm{B}$ and vermicompost shared better effects on growth and yield attribute significantly of Chilli (Capsicum annum L.). Better growth and yield were achieved in $\mathrm{B}_{0.5} \mathrm{~kg} / \mathrm{ha}+\mathrm{VC}_{5}$ ton/ha treatment and nutrient accumulation in the fruits was found in $\mathrm{B}_{0.5} \mathrm{~kg} / \mathrm{ha}+\mathrm{VC}_{5}$ ton/ha and $\mathrm{B}_{1.5}$ $\mathrm{kg} / \mathrm{ha}+\mathrm{VC}_{5}$ ton/ha treatments respectively.

\section{REFERENCES}

Adhikary, S. 2012. Vermicompost, the story of organic gold: A review. Agric. Sci. 3: 905-917.

Atarzadeh, S. H., M. Mojaddam and T. S. Nejad. 2013. The interactive effects humic acid application and several of nitrogen fertilizer on remobilization star wheat. Int. J. Bioscience. 3(8): 116-123.

Azarmi, R., M. T. Giglou and R. D. Taleshmikail. 2008. Influence of vermicompost on soil chemical and physical properties in tomato (Lycopersicum esculentum) field. African J. Biotechnology. 7: 2397-2401. 
Bardsley, C. E and J. D. Lancaster. 1965. Sulfur. In: C. A. Black (ed.) Methods of Soil Analysis. Part 2. American Society of Agronomy, Inc., Madison, Wisconsin, USA., pp. 1102-1114.

Hossain, S. T., M. J. Uddin and H. Sugimoto. 2012. Vermi-compost to improve tomato production in Bangladesh. Proceedings of the $3^{\text {rd }}$ international conference on conservation agriculture in Southeast Asia, on Dec 10-15, held in Ha Noi, Vietnam., pp. 262-262.

Jackson, M. L. 1965. Soil Chemical Analysis. Prentice-HallInc., New York, USA. 498 pp.

Jeyabal, A. and G. Kuppuswamy. 2001. Recycling of organic wastes for the production of vermicompost and its response in rice-legume cropping system and soil fertility. Eu. J. Agron. 15(13): 153-170.

Khadir, G. A., S. K. Marazat and S. A. Sadoun. 2002. Effect of different levels of urea fertilizers and plant spacing on growth and yield of cabbage. Dirasat. 16: 88-105.

Mordtvedt, J. J., F. R. Cox, L. M. Shuman and R. M. Welch. 1991. Micronutrients in Agriculture. Soil Sci. Soc. of America, Madison, Wisconsin, USA., pp. 280-339.

Olsen, S. R., C. V. Cole., F. S. Watanabe and L. A. Dean. 1954. Estimation of available phosphorus in soils by extraction with NaHCO3, USDA Cir.939. Washington, USA.

Petter, F. A., B. E. Madar, M. A. S. Silva, M. A. C. Caneiro, M. T. M. Caravalho, B. H. M. Junior and L. P. Pacheco. 2012. Soil fertility and agronomic response of rice to bio-char application in the Brazilian savannah. Pesquisa Agropecuarria Brasileira. 47(5): 699-706.

Pratt, P. F. 1965. Potassium. In: C. A. Black (ed.). Methods of Soil Analysis. Part 2. American Society of Agronomy, Inc., Madison, Wisconsin, USA., pp. 1022-1030.

Roy, R., A. Finck, G. Blair and H. Tandon. 2006. Plant Nutrition for Food Security: A Guide for Integrated Nutrient Management; FAO Fertilizer and Plant Nutrition Bulletin; FAO: Rome, Italy. Volume 16. 368pp.

Singh, R., R. R. Sharma, S. Kumar, R. K. Gupta and R. T. Patil. 2008. Vermicompost substitution influences growth, physiological disorders, fruit yield and quality of strawberry. Bioresour. Technol. 99: 8507-8511.

Theunissen, J.; P, Nhakidemi and C. P. Laublsher. 2010. Potential of vermicompost produced from plant waste on the growth and nutrient status in vegetable production. Int. J. Phys. Sci. 5: 1964-1973.

Vijayalakshmi, A. and V. Gayathri. 2017. Effect of vermicompost on the growth and yield of Chili. Intl. J. Recent Scientific Res. 8(8): 19540-19542.

Walkley, A. and I. A. Black. 1934. An examination of the degtjareff method for determining soil organic matter, and a proposed modification of the chromic acid titration method. Soil Sci. 37: 29-38.

Zaman, M. M., M. A. Rahman, T. Chowdhury and M. A. H. Chowdhury. 2018. Effects of combined application of chemical fertilizer and vermicompost on soil fertility, leaf yield and stevioside content of stevia. J. Bangladesh Agril. Univ. 16(1): 73-81. 
